the Royal Society considered these factors warranted immediate investigation by scientists while the eruption was still proceeding, and in November 1961 formed a committee to consider the possibility of dispatching scientists to the island.

During December 1961 two geologists made a brief reconnaissance visit to Tristan da Cunha aboard H.M.S. Jaguar by courtesy of the Royal Navy (Nature, 193, 719; 1962). This brief visit was followed in January 1962 by a twelve-man expedition which spent seven weeks on the island (Nature, 194,$1119 ; 1962)$. This expedition included four geologists, one botanist and one zoologist, and the summary of their preliminary results was reported at a discussion meeting of the Royal Society in February of 1963. A film which was largely taken by the members of the Royal Society expedition shows the development and growth of the volcano from the beginning of the eruption in October 1961 until March 1962, when active growth had virtually ceased. It also indicates some of the effects of the volcano on the flora and fauna of the island. The film is of approximately 20 -min duration, in colour, sound on film, and is available on hire at a charge of 25s. from the Executive Secretary, The Royal Society, Burlington House, W.1.

\section{Royal College of Science and Technology, Glasgow: Biological Engineering Research}

TrE Department of Mechanical Engineering of the Royal College of Science and Technology has received a grant of $£ 50,000$ from the Medical Research Council to support the further development of biological engineering research. 'Biological engineering' is a collective phrase used to describe the application of a wide range of specialist aspects of the physical sciences and of technology, in collaboration with the medical disciplines, to investigation of problems relating to the human body. There is already very considerable activity in biological engineering in Britain and abroad; yet the field is so wide and the problems so numerous that the present effort will have to be considerably intensified if the full potential of this collaboration is to be realized. Work in this field commenced at the Royal College of Science and Technology some six years ago with the application of refrigeration techniques in hypothermia, followed at a slightly later stage by the experimental studies of skin tensions in the human body. Since then, the College's research activity has greatly intensified in close cooperation with surgeons and physicians in Glasgow's teaching hospitals, combined teams drawn from the professions working in the College engineering laboratories, the hospital wards, the operating theatres and the medical research departments. The success of this co-operation has led to the creation of a College-based Biological Engineering Unit under the direction of Dr. R. M. Kenedi. The work will be carried out under the guidance of a Steering Committee composed of representatives of the Medical Units concerned and of the College.

\section{British Food Manufacturing Industries Research Asso- ciation}

Tre annual report for 1962 of the British Food Manufacturing Industries Research Association has recently been published. The research programme has been largely concerned with problems which arise in factories dealing with cocoa and chocolate, sugar confectionery, meat and fish products, preserves, pickles and sauces, oils and fats and baker's prepared materials. Apart from contributions to the general literature, the Association published during the year six research reports and nine. teen technical circulars. 'The 'analytical service' examined a total of 1,190 samples, of which 30 per cent were meat products for assessment of the proportion of meat present and 20 per cent were sugar products and chocolate for general composition. The special section dealing with extraneous materials handled 275 samples, of which 40 were rejected as failing to conform with U.S. requirements. Also 52 of the 81 samples examined for the Howard mould count failed to conform to presumptive U.S. tolerances. In addition, the 'bacteriological service' examined 978 samples, including 548 curing brines. The new library and information office came into full operation in September. The newly appointed director of research, Dr. C. L. Cutting, states in his report: "It should not escape official notice that although the largest single item amounting to between 20 and 25 per cent of the national outlay is food at $£ 5,000$ million a year, the total of about $£ 5$ million expenditure on technological research by the food manufacturing industry and Government combined is woefully inadequate compared with a number of other industries that are surely no more vital than food".

\section{Further Education for School Leavers}

A NEW booklet, entitled Further Education for School Leavers, which the Ministry of Education is sending to every secondary school in England and Wales, is intended to help teachers, and particularly careers masters and mistresses, to advise boys and girls as to the extent and variety of courses now available for those who wish to continue their education after leaving school (Pp. 40. London: Ministry of Education. 1963). The first two chapters deal with full-time courses for the sixth-form and fifth-year leaver, respectively; the third deals with other opportunities in further education, and the fourth with opportunities for girls, particularly in commerce, in science, in librarianship, management and catering, and in nursing. Enrolment, fees and grants are dealt with in a fifth chapter and lists of Colleges of Technology and of publications are appended. The booklet deals with the technical colleges as well as the universities, including also the social sciences, art, agriculture and commerce.

\section{Science Journalism}

The first Inter-American Seminar on Science Journalism was held in Santiago, Chile, during October 16-18, 1962, under the sponsorship of the Department of Scientific Affairs, Pan American Union, and of the Technical Centre of the Inter-American Press Association. The main purposes of the Seminar, the report of which is now published (Pp. iii + 30. Washington, D.C.: Department of Scientific Affairs, Pan American Union, Pan American Bldg. 1963. 35 cents), were to examine the techniques of science journalism, discuss some aspects of Latin American science, and promote better understanding among scientists and journalists. Besides abstracts of addresses given at the Seminar, the report includes the recommendation of the three committees appointed to deal with educational, information and administrative matters, respectively. The Committee on Educational Matters recommended universities to include in the programmes of schools of journalism and communications, curriculum courses in science journalism or chairs widening the traditional concepts that relate this work to humanism and philosophy. The universities and schools of journalism are also recommended to conduct seminars for professional journalists and schools of journalism in accordance with the science journalism programmes. The Committee also recommends to the Department of Scientific Affairs of the Pan American Union a programme including publication of a list of science writers, promoters and reporters in the hemisphere, publication of text-books popularizing science, translation and publication of didactic textbooks on journalism, organization of an Inter-American course for professors of scientific journalism, interchange of schools of journalism curricula, establishment of awards to outstanding science journalists, and possibly the foundation of a Latin American association of science journalists. 